ISAHP 2005, Honolulu, Hawaii, July 8-10, 2005

\title{
APPROPRIATENESS OF A MULTI-CRITERIA RATING MODEL: THE CASE OF ESTABLISHING RESCUE POLICIES FOR REGIONAL DRINKING WATER COMPANIES (PDAM) IN INDONESIA
}

\author{
Kirti Peniwati \\ PPM Graduate School of Management \\ Jl. Menteng Raya 9, Jakarta 10340, Indonesia \\ kirti@indo.net.id \\ Werner Brenner \\ The Indonesian Association of Water Companies (PERPAMSI) \\ Jl. Penjernihan II/27B, Pejompongan, Jakarta, Indonesia. \\ wbrenner@dnet.net.id
}

Keywords: AHP, rating model, drinking water companies, Water Enterprise Association, Indonesia.

Summary: Fresh water is in abundance in Indonesia, but it has not been evenly distributed within the country. Only about 20\% out of more than 200 millions of Indonesian population have access to clean water supplied by the 306 Regional Drinking Water Companies (PDAMs). The poor performance of most PDAMs is due to high level of debt, lack of investment, and inefficient operations. On one hand, the PDAMs need to increase its coverage capacity but on the other hand they have been operating under unfavorable regulated tariff policies. Indonesia's Water Enterprise Association (PERPAMSI) has been participating in a task force to propose financial policies to rescue the industry by rating and grouping the PDAMs using a multi-criteria framework. This paper proposes improvements to the model by maintaining the original priority judgments. Model-1 is the AHP representation of the original model, Model-2 is similar to Model-1 with the principle of hierarchic composition is satisfied, and Model-3 is a framework for multi-decisions decision making by clustering the PDAMs based on their business performance. Model-2 does not improve its usefulness for identifying specific group policies that fit the need of every PDAM in a given group. Model-3 enables one to identify a specific policy applicable for either the whole PDAMs or those grouped in a certain cluster, and rate the PDAMs based on a set of criteria that is relevant to that policy. The results of the three models are evaluated and some examples of using Model-3 framework to rate the PDAMs, each with a specific policy in mind, are provided.

\section{Introduction}

Fresh water is in abundance in Indonesia, but it has not been evenly distributed within the country. Provision of clean water still needs to be enhanced to meet people's basic needs especially in rural areas. It has been reported that at the beginning of the new millennium, only about $20 \%$ out of more than 200 millions of Indonesian population have access to clean water supplied by the 306 Regional Drinking Water Companies (PDAM) around the country . The poor performance of PDAM is due to high level of debt, lack of investment, and inefficient operations. On one hand, PDAMs need to increase its coverage capacity but on the other hand they are operated under unfavorable regulated tariff policies. The number of PDAM with long term liabilities are close to $70 \%$, with more than $90 \%$ of them have been penalized for not paying their debt as scheduled.

The government established a task force, in which representations from the Indonesia Water Enterprise Association (PERPAMSI) and other institutions have been collaborating in a program to rescue and increase the efficiency of the PDAMs. Some of the objectives of the program are increasing government's financial support and introducing full cost recovery to water service without compromising the need to serve the low-income communities. The team has established a rating model to prioritize the PDAMs with 
respect to how much they need financial support or/and management interventions to survive. The PDAMs are then grouped based on their scores and debt solution policies are recommended for each group. Thirty PDAMs were then selected for more detailed study, partly because the proposed policies are too broad with no clear distinction between policies for different groups.

The purpose of this paper is to show the original model and two alternative improvements after converting the original framework into an AHP model (Model-1). Model-2 is similar to Model-1, but ensuring that the principle of hierarchic composition is satisfied by removing internal dependency among criteria through a correlation test. Model-3 clusters the PDAMs based on their financial performance, making it useful to identify an appropriate policy and rate the PDAMs with that policy in mind using only criteria that are relevant for the purpose.

\section{Model 1: The Original Model}

The original rating model contains 13 criteria grouped into external factors and internal factors. The external factors are those considered as uncontrollable by the PDAMs, i.e., Water Source Bottleneck, Chemical and Electricity Costs, Idle Capacity, Tariff Ratio, Arrears to Short Term Debt for Loans Ratio, and Debt to Equity Ratio. The internal factors are controllable by the PDAMs, i.e., Non Revenue Water, Employees per 1000 Connections, Working Ratio, Collection Period, Current Ratio, Solvability Ratio, Coverage Ratio. A range of discrete points between 2 and 10 or between 2 and 20 are assigned for each factor, to be used in representing judgments regarding the quality of a PDAM with respect to that particular factor [Brenner, 2005]. External factors and internal factors are judged to be equally important and expressed by having the same total of maximum scores of the external as the internal set of criteria. As many as 167 PDAM were evaluated by assigning discrete points for each criterion to obtain overall scores that were then used to divide the PDAMs into five groups and recommend alternative policies for each group.

The model can be directly converted into an AHP model as shown in Fig.1, with the points represent intensity ratings of the AHP's absolute measurement approach. This implied an assumption that the discrete points used to represent judgments come from ratio scales.

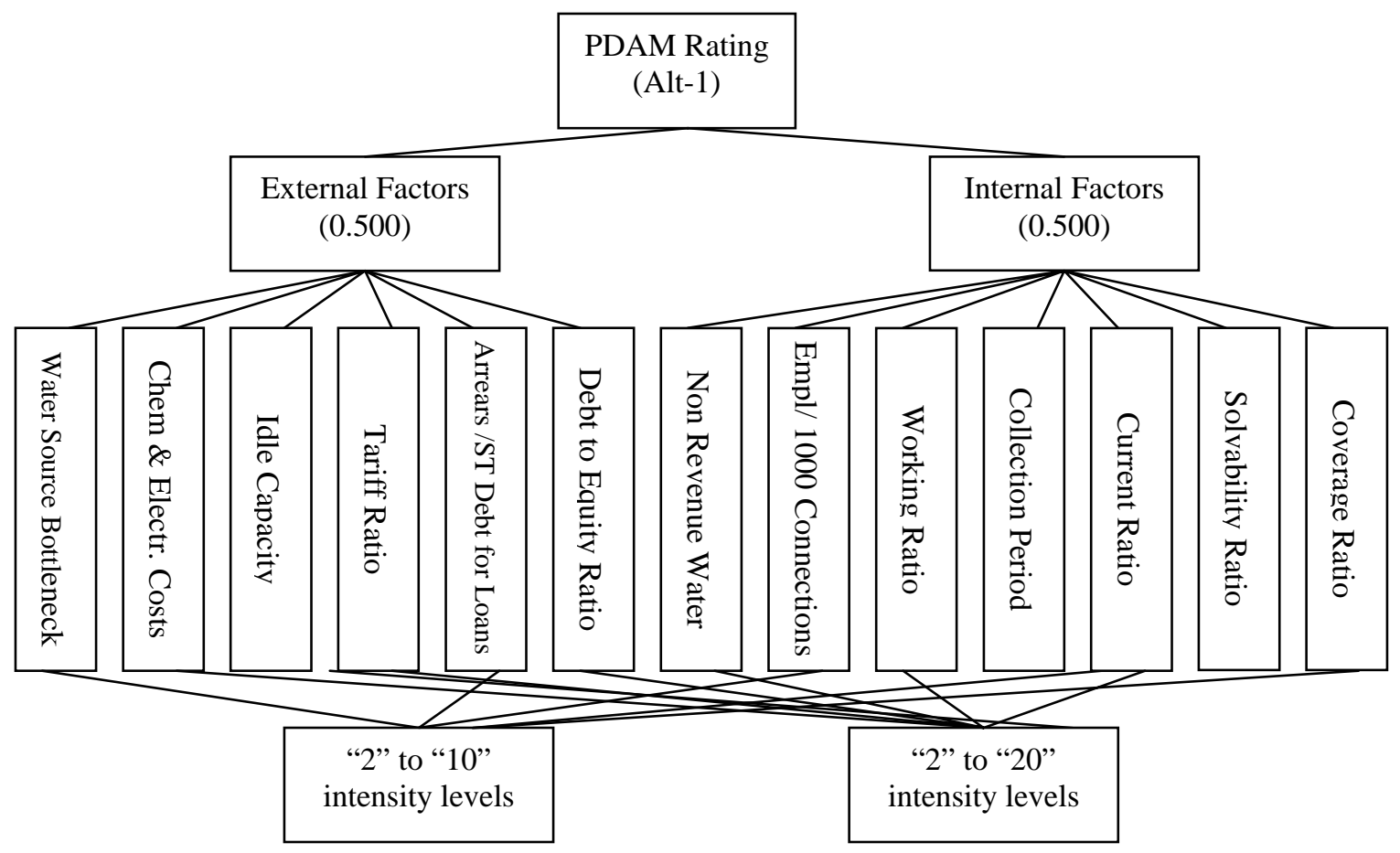

Figure 1. The AHP Representation of the Original Rating Model (Model-1) 
The AHP representation of the original model is a four level hierarchy with external factors and internal factors as the main criteria, judged as equally important. Sub-factors or criteria with maximum scores of 20 are judged as twice as important as those with maximum scores of 10 . Intensity ratings are noted using the numbers used, i.e., " 2 ", “4”, ..., “10”, ..., "20", each associated with a range of quantitative measures for each criterion. The numbers represent relative priority of the intensity ratings. The alternatives are evaluated by assigning a number from the set of intensity ratings, assumed to be ratios, hence can be normalized to get the AHP's $(0,1)$ priority scales. By entering the same intensity judgments, Model-1 produces the same overall PDAM rating scores as those of the original model. The scoring is such that the higher the number, the more troubled the PDAM is, hence the higher the priority for receiving government financial support. The global relative priorities of the criteria are a normalization of the maximum points of Model-1, as shown in Table 1 below:

Table 1. Points vs Relative Priorities of the Factors/Criteria (with dependency)

\begin{tabular}{|c|c|c|}
\hline Factors/Criteria & Maximum Points & Global Priority \\
\hline \multicolumn{3}{|l|}{ External factors (uncontrollable by PDAM) } \\
\hline Water Source Bottleneck & 10 & 0.050 \\
\hline Chemical and Electricity Costs & 20 & 0.100 \\
\hline Idle Capacity & 20 & 0.100 \\
\hline Tariff Ratio & 20 & 0.100 \\
\hline Arrears to Short Term Debt for Loans Ratio & 10 & 0.050 \\
\hline Debt to Equity Ratio & 20 & 0.100 \\
\hline Total & 100 & 0.500 \\
\hline \multicolumn{3}{|l|}{ Internal factors (controllable by PDAM) } \\
\hline Non Revenue Water & 20 & 0.100 \\
\hline Number of Employees per 1000 Connections & 10 & 0.050 \\
\hline Working Ratio & 20 & 0.100 \\
\hline Collection Period & 10 & 0.050 \\
\hline Current Ratio & 20 & 0.100 \\
\hline Solvability Ratio & 10 & 0.050 \\
\hline \multirow[t]{2}{*}{ Coverage Ratio. } & 10 & 0.050 \\
\hline & 100 & 0.500 \\
\hline
\end{tabular}

Table 2. The Original Grouping and Proposed Policies

\begin{tabular}{|c|c|c|c|}
\hline Group & $\begin{array}{l}\text { Total } \\
\text { Points }\end{array}$ & Proposed Policy & $\begin{array}{l}\text { Number of } \\
\text { PDAM }\end{array}$ \\
\hline $\begin{array}{c}1 \\
\text { Very Weak }\end{array}$ & $86-100$ & $\begin{array}{l}\text { - Write off all unpaid interest, debt, and commitment fee. } \\
\text { - } \quad \text { Debt restructuring / write off unpaid principal. }\end{array}$ & $4(2.4 \%)$ \\
\hline $\begin{array}{c}2 \\
\text { Weak }\end{array}$ & $71-85$ & $\begin{array}{ll}\text { - } & \text { Write off all unpaid interest and debt. } \\
\text { - } & \text { Debt restructuring / write off unpaid principal }\end{array}$ & 46 (27.5\%) \\
\hline $\begin{array}{c}3 \\
\text { Inadequate } \\
\end{array}$ & $56-70$ & $\begin{array}{ll} & \text { Write off all unpaid interest and debt. } \\
\text { - } & \text { Write off unpaid principal. } \\
\end{array}$ & $64(38.3 \%)$ \\
\hline $\begin{array}{c}4 \\
\text { Adequate }\end{array}$ & $41-55$ & $\begin{array}{ll} & \text { Write off all unpaid penalty } \\
\text { - } & \text { Debt restructuring }\end{array}$ & $45(27.0 \%)$ \\
\hline $\begin{array}{c}5 \\
\text { Strong }\end{array}$ & $13-40$ & - $\quad$ Debt restructuring & 8 (4.8%) \\
\hline
\end{tabular}


The PDAMs are categorized into 5 groups based on the scores obtained from the model, ranging from very weak to strong. The five categories of PDAMs with the recommended policies for each group are shown in Table 2 above.

\section{Model-2 : A Hierarchy that Satisfies the Principle of Hierarchic Composition}

The outcome of Model-1 is valid only if the Principle of Hierarchic Composition (Saaty, 1994) is satisfied, i.e., the factors are independent. We conducted a correlation test for the set of factors in the original model (Model 1) and the result is shown in Table 3 below:

Table 3. Results of Correlation Test for Model 1

\begin{tabular}{|l|l|}
\hline \multicolumn{1}{|c|}{ Criteria as Variables } & \multicolumn{1}{|c|}{ Degree of Correlation } \\
\hline $\begin{array}{l}\text { Current Ratio } \\
\text { Solvability Ratio } \\
\text { Water Source Bottleneck } \\
\text { Idle capacity } \\
\text { Debt to Equity Ratio }\end{array}$ & $\begin{array}{l}\text { No significant correlation } \\
\text { No significant correlation } \\
\text { No significant correlation } \\
\text { No significant correlation } \\
\text { No significant correlation }\end{array}$ \\
Non Revenue Water and Collection Period & Significant at the 0.05 level (2-tailed) \\
Coverage Ratio and Arrears to Short Term Debt for Loan Ratio \\
$\begin{array}{l}\text { Coverage Ratio and Tariff Ratio } \\
\text { Employees per 1000 Connections and Working Ratio } \\
\text { Employees per 1000 Connections and Collection Period } \\
\text { Working Ratio and Chemical and Electricity Costs } \\
\text { Collection Period and Chemical and Electricity Costs } \\
\text { Collection Period and Tariff Ratio }\end{array}$ & $\begin{array}{l}\text { Significant at the 0.01 level (2-tailed) } \\
\text { Significant at the } 0.01 \text { level (2-tailed) } \\
\text { Significant at the 0.01 level (2-tailed) } \\
\text { Significant at the } 0.01 \text { level (2-tailed) } \\
\text { Significant at the } 0.01 \text { level (2-tailed) } \\
\text { Significant at the } 0.01 \text { level (2-tailed) } \\
\text { Significant at the } 0.01 \text { level (2-tailed) }\end{array}$ \\
\hline
\end{tabular}

The presence of significant correlations between criteria indicates that Model 1 violates the principle of hierarchic composition (axiom of independence), which may lead to invalid outcome. Taking into consideration only significant correlations at the 0.01 level, we obtained nine (assumed) independent factors as follows: Non Revenue Water, Collection Period, Coverage Ratio, Working ratio, Current Ratio, Solvability Ratio, Water Source Bottleneck, Idle Capacity, and Debt to Equity Ratio. When there is a significant correlation between an internal factor and an external factor, we chose the internal factor to make the improved model creates a sense that the PDAMs is more in control of their companies' future. We propose Model-2 to improve Model-1 such that the principle of hierarchic composition is satisfied.

To maintain the equivalency between Model-2 and the original model regarding judgments of relative priorities, the relative priority of the External Factors and Internal Factors must be maintained to be proportional to the total maximum points of the new set of criteria which represents relative priorities.the External Factors and Internal Factors elements. In this case, the relative priorities of External and Internal Factors elements become 0.357 and 0.643 respectively. The AHP model for Model- 2 with the global priorities associated with the points assigned by the team are shown in Fig. 2 and Table 3 below. 


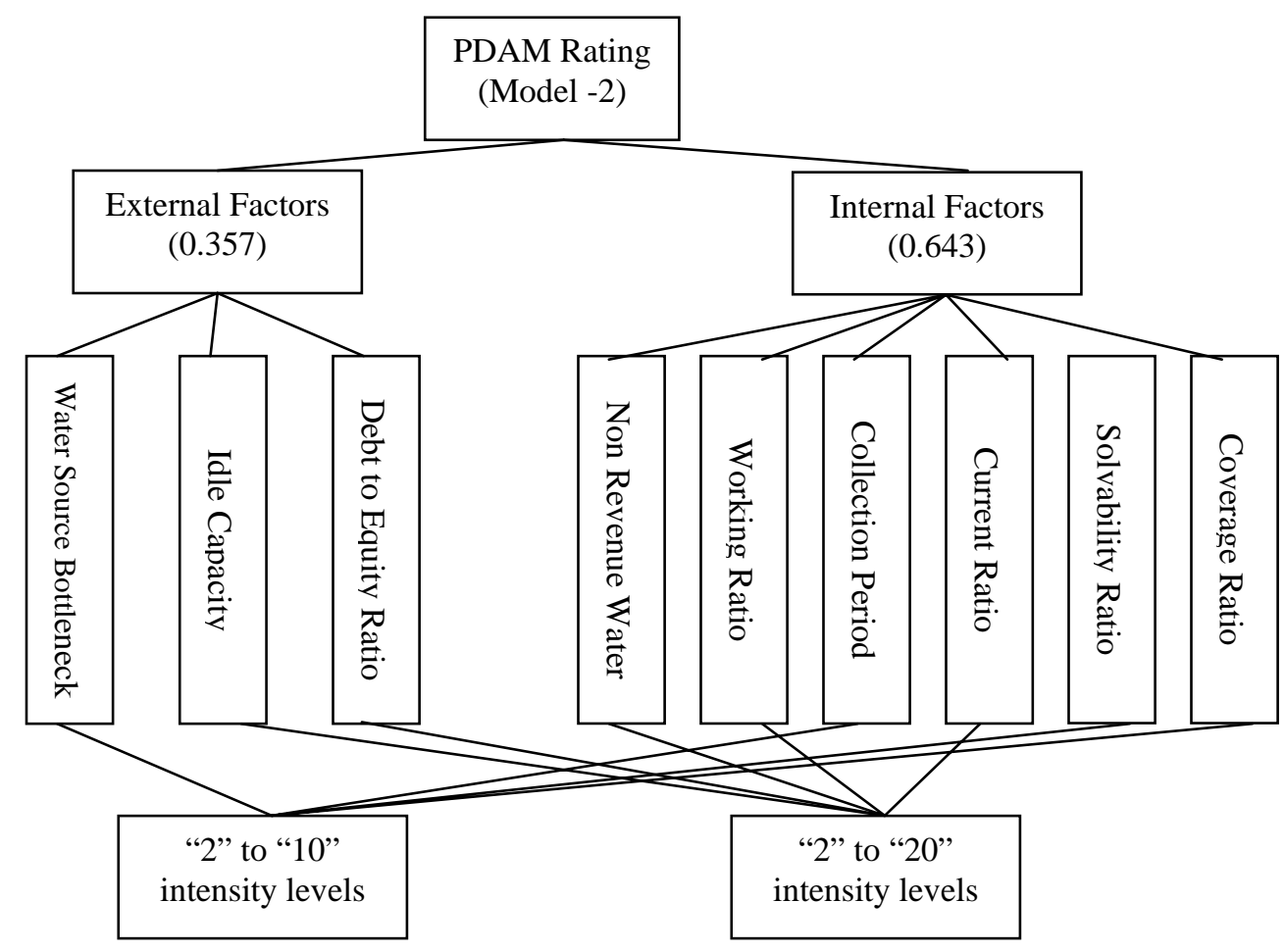

Figure 2. AHP Representation of the Original Model with Independent Criteria

Table 4. Points vs Relative Priorities of the Factors/Criteria (significant dependency removed)

\begin{tabular}{|c|c|c|}
\hline Factors/Criteria & Maximum Points & Global Priority \\
\hline $\begin{array}{l}\text { External factors (uncontrollable by PDAM) } \\
\text { Water Source Bottleneck } \\
\text { Idle Capacity } \\
\text { Debt to Equity Ratio } \\
\\
\underline{\text { Internal factors (controllable by PDAM) }} \text { Total } \\
\text { Non Revenue Water } \\
\text { Working Ratio } \\
\text { Collection Period } \\
\text { Current Ratio } \\
\text { Solvability Ratio } \\
\text { Coverage Ratio. }\end{array}$ & $\begin{array}{l}10 \\
20 \\
20 \\
50 \\
\\
20 \\
20 \\
10 \\
20 \\
10 \\
10 \\
\end{array}$ & $\begin{array}{l}0.071 \\
0.143 \\
0.143 \\
0.357 \\
\\
0.143 \\
0.143 \\
0.071 \\
0.143 \\
0.071 \\
0.071 \\
\end{array}$ \\
\hline Total & 90 & 0.643 \\
\hline
\end{tabular}

\section{Model 3: A Model with Clustering Based on Business Performance}

Model-1 and Model-2 take all PDAMs as one population, and group them in increasing order based on their scores. Applying a multi-criteria rating model like this does not seem to help in designing a common rescue policy that is applicable for each group. We would argue that financial policies need to be based on 
business performance using financial indicators. For this reason, the appropriate framework would be one that clusters the PDAMs based on those indicators. The process can be done with the line of thinking as described below, that can also be represented in a diagram shown in Figure 3:

- PDAMs with negative equity but continuously show working ratio below $100 \%$ do not have a business justification to operate anymore. Maintaining their operation means that they are subsidized operations for public service. From a purely business perspective, they are in a bankruptcy status and need to be liquidated. They are grouped in Cluster A.

- PDAMs with negative equity but working ratio more than $100 \%$ are also technically bankrupt, but still have the capacity to continue their operation as long as they are not burdened with depreciation cost and interests. They are grouped in Cluster B.

- PDAMs with positive equity but continuously show working ratio below $100 \%$ are approaching bankruptcy. It is just a matter of time, and they are grouped in Cluster C.

- PDAMs with positive equity, working ratio above $100 \%$ but tariff ratio below $100 \%$ do not have the capacity to maintain their fixed assets. They are not profitable businesses and grouped as Cluster D.

- PDAMs with positive equity, working ratio above $100 \%$, and tariff ratio above $100 \%$, are profitable businesses. They are grouped as Cluster E.

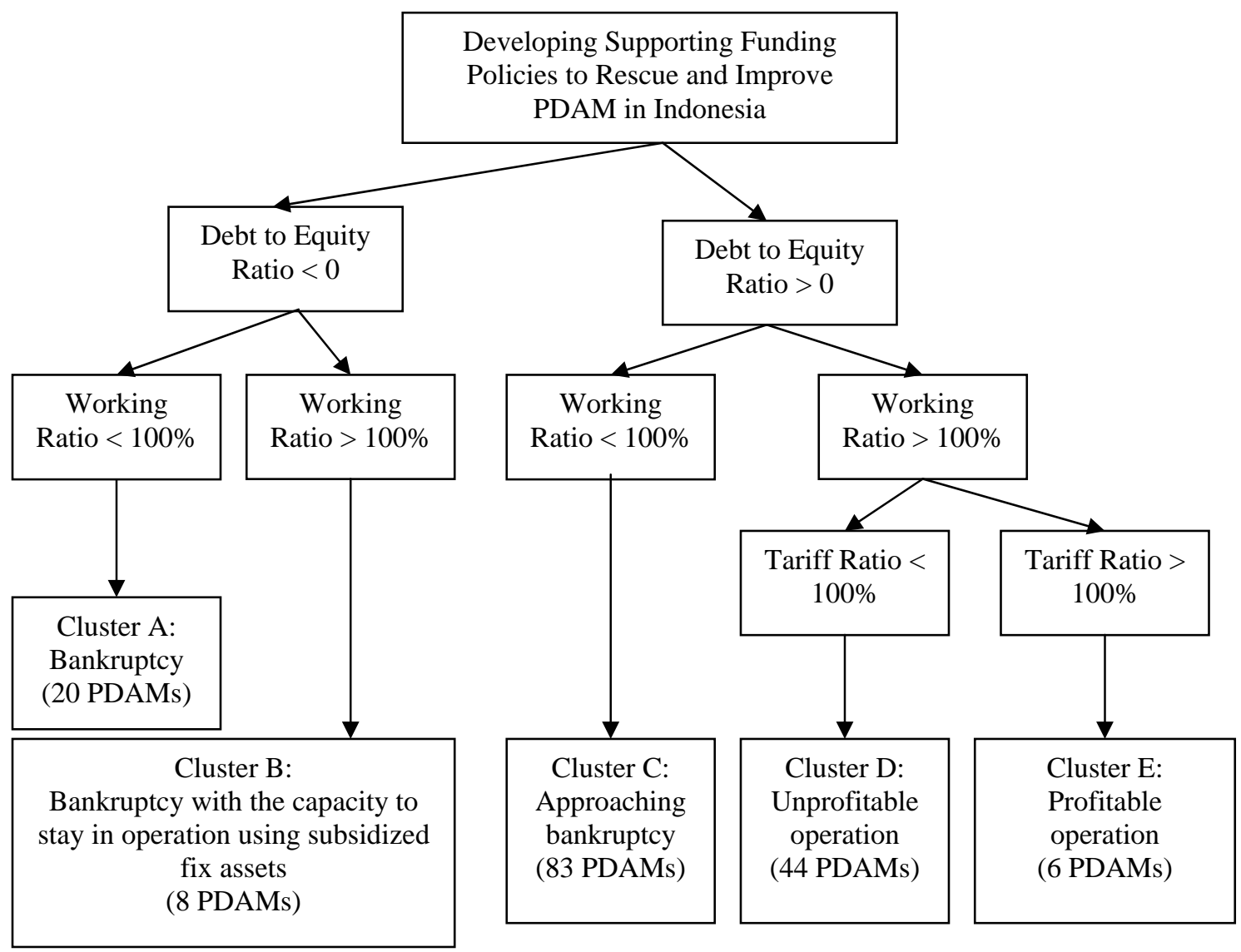

Figure 3. Clustering of PDAMs Based on Business Performance

\section{Analysis of the Different Models}

Model-1 and Model-2 put all PDAMs in one population while Model -3 groups them in clusters based on their business conditions. While Model-1 and Model-2 use a range of rating scores to indicate an 
appropriate rescue policy, Model-3 allows rating to prioritize PDAMs in a given group with a specific policy in mind.

\subsection{Model-1 and Model-2 are Significantly Correlated}

A correlation test between PDAM's groupings as shown by Model-1 and Model-2 outcomes gives a Pearson Correlation of 0.859 , which is significant at the 0.01 level. The difference in grouping, uswing the same cut-off points, is never more than 1 as shown below:

- 112 (68 \%) PDAMs grouped the same.

- 12 (7 \%) PDAMs grouped lower (worse) by Model-2 than by Model-1

- 43 (26 \%) PDAM grouped higher (better) by Model-2 than by Model-1

This finding must not lead to a conclusion that satisfying the principle of hierarchic composition is not necessary for a hierarchy. It is true, however, that improvement in Model 2 does not add to its usefulness for designing rescue policies. Model 1 and Model 2 give different numbers of PDAM in each group as shown in Table 5 below. Despite its significant correlation, it is interesting to observe that Model-1 rated only 8 PDAMs as strong while Model-2 rated as many as 24 PDAMs in this top group.

Table 5. Grouping of PDAMs Using Model 1 and Model 2

\begin{tabular}{|c|c|c|c|c|c|}
\hline \multirow{2}{*}{ Group } & \multirow{2}{*}{$\begin{array}{c}\text { Total } \\
\text { Points }\end{array}$} & \multicolumn{4}{|c|}{ Number of PDAM } \\
\cline { 3 - 6 } & & Number & $\%$ & Number & $\%$ \\
\hline $\begin{array}{c}1 \\
\text { Very Weak }\end{array}$ & $86-100$ & 4 & 2.4 & 5 & 29.9 \\
\hline $\begin{array}{c}2 \\
\text { Weak }\end{array}$ & $71-85$ & 46 & 27.5 & 40 & 24.0 \\
\hline $\begin{array}{c}3 \\
\text { Inadequate }\end{array}$ & $56-70$ & 64 & 38.3 & 57 & 34.1 \\
\hline $\begin{array}{c}4 \\
\text { Adequate }\end{array}$ & $41-55$ & 45 & 27.0 & 41 & 24.6 \\
\hline $\begin{array}{c}5 \\
\text { Strong }\end{array}$ & $13-40$ & 8 & 4.8 & 24 & 14.4 \\
\hline
\end{tabular}

\subsection{Model-3 Facilitate Purposeful Ratings}

Model-3 uses a decision tree structure to cluster the PDAMs into homogeneous groups. The different numbers of PDAMs in each group by the three models are shown in Table 6 below. The total number of PDAMs in this table is only 157 instead of 167 because of incomplete data. This table shows the significant difference between the outcome of Model-3 and Model-1 or Model-2. For example, PDAMs in Cluster C (those approaching bancruptcy) are scattered in all groups from the worst (Group 1) to the best (group 5) by Model-1 and Model-2. We have 20 PDAMs in Cluster A (those in a bancruptcy state), but only four of them fall in Group 1 (very weak) with Model 1 and Model 2.

These results show the problematic nature of using a single multi-criteria rating model for the whole population of PDAMs with a wide range of business performance levels. Such a rating model does not facilitate the identification of a unique policy for each group that represents their different positions in the rating process. 
Table 6. Different Groupings of PDAMs by Different Models

\begin{tabular}{|c|c|c|c|c|c|c|c|c|c|c|}
\hline \multirow{2}{*}{ Model 3 } & \multicolumn{4}{|c|}{ Model 1 } & \multicolumn{5}{|c|}{ Model 2 } \\
\cline { 2 - 12 } & $\begin{array}{c}\text { Group } \\
1\end{array}$ & $\begin{array}{c}\text { Group } \\
2\end{array}$ & $\begin{array}{c}\text { Group } \\
3\end{array}$ & $\begin{array}{c}\text { Group } \\
4\end{array}$ & $\begin{array}{c}\text { Group } \\
5\end{array}$ & $\begin{array}{c}\text { Group } \\
1\end{array}$ & $\begin{array}{c}\text { Group } \\
2\end{array}$ & $\begin{array}{c}\text { Group } \\
3\end{array}$ & $\begin{array}{c}\text { Group } \\
4\end{array}$ & $\begin{array}{c}\text { Group } \\
5\end{array}$ \\
\hline $\begin{array}{c}\text { Cluster A } \\
20\end{array}$ & 4 & 12 & 4 & 1 & - & 4 & 12 & 4 & 1 & - \\
\hline $\begin{array}{c}\text { Cluster B } \\
8\end{array}$ & - & 3 & 4 & 1 & - & - & 4 & 3 & 1 & - \\
\hline $\begin{array}{c}\text { Cluster C } \\
83\end{array}$ & 1 & 23 & 33 & 23 & 1 & 1 & 19 & 32 & 21 & 8 \\
\hline $\begin{array}{c}\text { Cluster D } \\
44\end{array}$ & - & 6 & 19 & 12 & 6 & - & 4 & 13 & 14 & 12 \\
\hline $\begin{array}{c}\text { Cluster E } \\
4\end{array}$ & - & - & - & 3 & 1 & - & - & 1 & 1 & 2 \\
\hline
\end{tabular}

\section{Purposeful Rating with Model-3}

The purpose of a rating assessment dictates what criteria to use in the model. Hence, a rating model needs to be constructed with a specific purpose in mind to be useful. In this PDAM case, it seems obvious that the different business conditions would need different interventions, be it financial or managerial policies. In this case, rating by cluster may be more helpful. Below are some examples of policies with their appropriate rating with the Model-3 basic structure.

\section{Capacity to Pay Debt}

The PDAMs are not fully accountable for their situation of deeply in debt because it was more the central government who made the foreign loan decisions in the past. For this reason, many PDAMs do not seem to feel obliged to pay their debt even when they have the financial capacity to do so. Rating based on Current Ratio is useful to see the PDAMs relative financial liquidity, indicating their level of capacity to pay their short term debt. There are 62 PDAMs with Current Ratio higher than 100\%, 37 of them are rated the best by this criterion (scored "2"). The 37 most liquid PDAMs are spread in Groups 3, 4, 5 by Model-1 and Clusters C, D, E by Model-3 as follows

Table 7. Distribution of PDAMs Rated the Best in Current Ratio

\begin{tabular}{|c|c|c|c|}
\hline & \multicolumn{3}{|c|}{ Number of PDAMs } \\
\cline { 2 - 4 } & Group 3 & Group 4 & Group 5 \\
\hline Cluster C & 7 & 12 & 1 \\
Cluster D & 5 & 3 & 5 \\
Cluster E & - & - & 1 \\
\hline
\end{tabular}

PDAMs in Cluster C by Model-3 are those with Working Ratio less than $100 \%$, which are expected not to be able to pay their debt because of liquidity problem. The fact that their financial conditions are highly liquid may indicate that the Working Ratio problem is just temporary, so they may not really approaching bancruptcy. PDAM Kab. Jombang is clustered in C but curiously not only is the most liquid of all but also has extremely high Current Ratio. This PDAM is deeply in debt, with debt penalty almost half of its capital loan. Assuming that the data is accurate, this PDAM may not belong to this cluster and has some capacity to pay its debt but is not willing to do so. This PDAM belongs to the Adequate Group 4 by Model-1. The two PDAMs from Cluster E, PDAM Kota Malang and PDAM Kota Payakumbuh, have no interest payable, indicating discipline in paying short term debt. 
Not only that PDAM Kota Malang and PDAM Kota Payakumbuh have no interest payable, they also are free of debt penalty. They can be considered as the best PDAM from the financial performance, but only PDAM Kota Payakumbuh belongs to the strong Group 5 by Model-1. PDAM Kota Malang is rated as adequate (Group 4) by this model. The two PDAMs obtain good rating under solvability ratio.

One may want to rate PDAMs with respect to their overall capacity to pay debt by using Current Ratio and Solvability Ratio. There are 28 PDAMs rated the best, but only 15 of them free of interests and debt penalty payables. The government may need to financially rescue 30 PDAMs that are rated the worst in both criteria.

\section{$\underline{\text { Tariff Increase }}$}

Tariff increase is under the control of local government, a decision that is heavy with social and political considerations. This policy would improve PDAM's survival ability through increasing Working Ratio or Tariff Ratio. Tariff increase can be applied to all PDAMs, but priority may be given to those PDAMs which this policy could move them from Cluster A to Cluster B or from Cluster D to Cluster E.

PDAMs in Cluster A have no business justification to exist anymore, however the government may not want to close them because provision of clean water around the country still needs to be enhanced. In this situation, implementing a rescue intervention to move the PDAMs from Cluster A to Cluster B may be preferable rather than liquidate them. One way to do it is by increasing tariff, but cannot be too significant for obvious reasons. This means that tariff adjustment would work only for PDAMs with Working Ratio relatively close to $100 \%$. For example, reasonable tariffs increase in PDAM Kab. Purbalingga or PDAM Kota Blitar with working ratio $99 \%$ and $92 \%$ respectively is likely to make a difference, but it may not be for PDAM Kab. Rembang whose Working Ratio is 37\%.

With the same line of reasoning, a reasonable tariff increase for PDAMs in Cluster D whose Tariff Ratio is close to $100 \%$ will be enough to move them to Cluster E. Tariff increase for PDAM Kota Balikpapan, PDAM Kab. Temanggung, PDAM Kota Palembang, and PDAM Yogyakarta with Tariff Ratio higher than $90 \%$ will be likely to move them to Custer E. PDAM Kota Semarang, PDAM Kab. Kutai, or PDAM Kota Makasar are the worst with Tariff Ratio of $11 \%$ or less.

Here, even a simple rating model with only a single criterion (Working Ratio or Tariff Ratio) is appropriate and useful to identify PDAMs whose business status can be significantly improved by tariff increase.

\section{Management Intervention to Improve Operational Efficiency}

Similar to increasing tariff, management intervention to improve operational efficiency is applicable to all PDAMs. The independent criteria indicating opportunity for improvements are Non Revenue Water, Collection Period, and Coverage Ratio. Here the government may want to prioritize PDAMs based on their relative leverage for such intervention. It is assumed that the highest absolute rating for any of these criteria means most opportunity for improvement. Five PDAMs are top rated in all three criteria, implying the highest leverage for management intervention. They are PDAM Kota Pekan Baru (Cluster A), PDAM Tirta Nciho Kab. Dairi (Cluster A), PDAM Kab. Sumbawa (Cluster C), PDAM Kab. Rejang Lebong (Cluster D), and PDAM Kab. INHU (Cluster D). PDAM Kab. Takalar (Cluster D) is rated the best in all criteria, implying the lowest leverage or relatively no opportunity for improving operational efficiency.

The government may particularly want to move PDAMs from Cluster A to B or from Cluster D to Cluster E by improving operational efficiency. PDAM Kota Pekan Baru and PDAM Tirta Nchico Kab. Dairi are top rated for all criteria, providing the best leverage for management intervention to move them from Cluster A to Cluster B, while PDAM Kab. Wonosobo is rated the lowest. 


\section{Rating for Cluster E}

PDAMs in Cluster E are profitable businesses, which may not need government financial support. The four PDAMs in this category do not have outstanding debt penalty, indicating that they all have the discipline to pay the debt. PDAM Kab. Purwakarta has the lowest Current Ratio of $42 \%$ with no debts in interests and penalty - indicating an excellent discipline in paying debt but may create other problems due to the poor liquidity.

and PDAM Kota Pare-Pare have inadequate Current Ratio with Only two of the four PDAMs in this category have current ratio above $100 \%$, but all four have or its support to increase their capacity to pay debt. There are several alternative policies that can be implemented, such as debt restructuring, tariff increase, or management intervention to increase operational efficiency. We have more than one way to rate the PDAMs in this cluster.

\section{Conclusion}

It is important to develop a model that is an appropriate representation of the decision at hand. This paper shows that treating a multi decisions problem as a single decision problem could lead to useless outcome, as has been shown by Model-1 and Model-2. Multi decisions problem may take the form of a list of independent set of decision problems, in which AHP can be used to prioritize them. Model-3 is an example of how AHP can be applied in Multi Decisions Decision Making with dependency. The framework of Model-3 is recommended to be used in this context, to facilitate designing appropriate policies for a number of PDAMs with similar situation.

Robert C. G. Varley, a Staff Consultant, Asian Development Bank (Manila) does not seem to be alone when he suggests that "The best way of addressing chronic and intractable deficiencies in PDAM management and governance is privatization, and a sound regulatory framework." However, we should define privatization more as managing PDAMs the way private companies do, rather than allowing private investors control this business.

\section{References}

Brenner, W. (2005), The Indonesian Association of Water Companies (PERPAMSI), Pengelompokan PDAM Berdasarkan Faktor Internal.

Brenner, W. (2005), The Indonesian Association of Water Companies (PERPAMSI), Pengelompokan PDAM Berdasarkan Faktor Eksternal.

Brenner, W. (2005), The Indonesian Association of Water Companies (PERPAMSI), Rekapitulasi Faktor Eksternal, Faktor Internal dan Ranking Dep. Keuangan.

Debt Solution Task Force, Condition and Problems of PDAM, Working Paper.

Saaty, T.L. (1990), Fundamentals of Decision Making and Priority Theory with the Analytic Hierarchy Process, RWS Publication, Pittsburgh, PA.

Varley, R. C. G. (2001), INDONESIA: Financing Small Scale Urban Infrastructure In the Era of Decentralization. Asian Development Bank (Manila), Internet. 